\title{
VARIETAL FORMS OF PERIPATUS IN HAITI.
}

\section{By Charles T. BRUes}

\author{
Biological Laboratories, Harvard University
}

During the past year Dr. P. J. Darlington of the Museum of Comparative Zoölogy spent some time in the Republic of Haiti where he obtained extensive collections of insects and other arthropods. Among this material are four lots of Onychophora taken at separated localities, including altogether 23 specimens. Previous to this there seem to have been discovered in Haiti only two specimens of Onychophora. These were contained in collections made by Dr. William M. Mann in 1912 and were dealt with by the writer in a previous paper. ${ }^{1}$

On account of striking differences in color and in the form of the integumentary papillæ, I considered Mann's specimens to represent two species, one of these I regarded as a subspecies of $P$. dominicæ Pollard of which the typical form inhabits the Island of Dominica while two other varieties occur on Antigua and Porto Rico respectively. The other form was named $P$. manni after its discoverer.

A close examination of the material obtained by Dr. Darlington discloses the fact that there are other forms of Peripatus in Haiti which appear to be clearly distinguishable from one another and furthermore that these appear to occupy separated regions or different ecological situations. I find also that he has rediscovered the two forms taken by Mann in the vicinity of the type locality near Furcy.

In order to present more clearly the differential characters of these several very similar forms, the following table has been constructed. It will be seen that the characters used are quite probably of different value, at least in our present state of knowledge. The form and arrangement of

${ }^{1}$ Preliminary Descriptions of two new Forms of Peripatus from Haiti. Bull. Mus. Comp. Zool., Harvard, vol. 54, pp. 519-521 (1913). 
the papillæ are subject to some individual variation, but on the whole seem to be reasonably constant. Variations in the form and attachment of the nephridial tubercles are also subject to but slight variation. On the other hand, such characters as the dentition of the mandibles and the number of leg-bearing segments are subject to sufficient variation to render them of lesser importance in the absence of other more distinctive characters. Nevertheless it seems that the characters used in the table are sufficient to indicate clearly that the several forms are racially distinct. This conclusion is borne out by very striking differences in the insect fauna of the several areas which have been observed by Dr. Darlington. The three moist mountain ranges from which the Peripatus come are separated by low, dry, highly xerophytic areas into which such animals are utterly unable to penetrate, and it is certain that no migration has occurred since such conditions became established. The failure of certain genera of flightless Carabidæ to bridge these gaps is clear evidence that these mountains are actually isolated after the fashion of true islands. In this respect Haiti is quite different from the other West Indian Islands on which Peripatus is known to occur since it affords clearly isolated mountain ranges. So far none have been discovered in Cuba, but two very distinct types are known from Jamaica, both inhabiting the extensive and continuous Blue Mountain Region in the eastern part of the Island. These appear to be very local in occurrence, and commonly associated at the same places. One, $P$. juliformis, var. swainson Ckll. is a true Peripatus, but the second which occurs with it is a modified type now relegated to the genus Plicatoperipatus. The occurrence of Onychophora in Jamaica is, however, so far as known, restricted to the Blue Mountains as none have been discovered in other parts of the island.

I have hesitated to propose any new taxonomic names, but as the material seems to justify some recognition of the five more or less readily distinguishable forms known from Haiti, those not already named are regarded as varietal forms. In general body color all are essentially similar, very dark in life, but after preservation in alcohol showing 
a very dark, beaded dorsal stripe the enlargements of which correspond to the body segments. Just lateral to the stripe is a narrow pale border which serves to render it quite conspicuous, especially in some specimens. The nephridial tubercles are practically of the same conformation in all of the forms. They are attached slightly or free from the third band which is emarginate and the fourth band is bent, but scarcely emarginate next to the tubercle.

\section{Key to the Forms of Peripatus known from Haiti}

1. Some of the primary papillæ on the integumentary folds clearly much larger than the remainder and arranged in such a way that one or several smaller ones are regularly interpolated between two large ones

Primary papillæ variable in size but not showing a definite arrangement on the folds with regard to size, $i$. e., the largest papillæ are not regularly spaced with reference to intervening smaller ones; very few or almost no accessory papillæ

2. A number of accessory papillæ present along the sides of the body folds

Accessory papillæ very few in number, almost absent; 30-33 pairs of legs in the female; blade of mandible with 14 teeth Peripatus dominicæ Pollard, var. lachauxensis, var. nov.

3. A bright orange spot at each side of the head (sometimes white in specimens that have been bleached by preservation in alcohol) ; mandible with 11-12 teeth ; 30-31 pairs of legs in the female Peripatus manni Brues. No pale markings of this kind present; body uniformly dark above, except for the shaded, dorsal pattern; blade of mandible with 8-10 teeth; 30-32 pairs of legs in the female Peripatus dominicæ Pollard, var. haitiensis Brues.

4. 28 pairs of legs in the female; mandible with 11 teeth

Peripatus dominicæ Pollard, var. basilensis, var. nov. 33-34 pairs of legs in the female; mandible with 9 teeth. Peripatus dominicæ Pollard, var. darlingtoni, var. nov. 


\section{Peripatus manni Brues.}

Bull. Mus. Comp. Zoöl., vol. 54, p. 520 (1913).

Six females and one male from near La Vesite, La Selle Plateau, Haiti (5,000-7,000 ft.), September 16-23, 1934 (P. J. Darlington). These are practically from the type locality which is near Furcy that lies just to the north of Vesite, and they were taken at practically the same altitude. The females have from 30-31 pairs of legs, two with the former and three with the latter number. The single male has 29 pairs. The conspicuous pale spot at the side of the head is present in both sexes.

Peripatus dominicæ Pollard, var. haitiensis Brues.

Bull. Mus. Comp. Zoöl., vol. 54, p. 519 (1913).

Of this form Dr. Darlington secured eight females and two males at the same place as the previous species, which is again practically the type locality. The occurrence of the two thus together suggests of course that they may be only color forms of one another although no such condition has been found to prevail elsewhere in the group which now includes about one hundred species. Among the American forms only Peripatus torquatus has a color pattern similar to that of $P$. manni; in this case the spots are almost united to form a transverse yellow band behind the head, and appear to be a constant specific character. Morphological differences are slight, as indicated in the key, and the general arrangement of the of the integumentary papillæ is much the same although there are fewer accessory papillæ in haitiensis.

Peripatus dominicæ Pollard, var. lachauxensis, var. nov.

This form is represented by two specimens from Etang Lachaux, taken October 27, 1934 by Dr. Darlington at an altitude of less than 1,000 ft. This locality is in the southeastern foot.-hills of the Massif de la Hotte in the southeastern peninsula of Haiti. It is much nearer to sea-level than any of the others and is consequently much drier. As indicated in the key this variety differs from the preceding forms by the almost complete absence of accessory papilllæ 
on the body folds and an unusually large number of small teeth on the blade of the mandible.

This is based on a single female from Mount Basil in northern Haiti taken at an altitude of about 4,000 feet on September 9, 1934 by Dr. Darlington.

Peripatus dominicæ Pollard, var. basilensis, var. nov.

This specimen has only 28 pairs of legs and a single large embryo which we have been able to remove by dissection shows the same number. The sex of the embryo cannot be determined and may of course be male, but the female shows that this form has an unusually small number of legs. As indicated in the key this variety is distinguishable from the preceding forms by the arrangement of the primary integumentary papillæ.

Peripatus dominicæ Pollard, var. darlingtoni, var. nov.

This is represented by two females and one male from Massif de la Hotte in the southwestern peninsula of Haiti taken between Camp Perrion and Mafin at an elevation of about 3,000 feet. The locality is near that where the variety lachauxensis was taken, but at a higher altitude and consequently in the moist rain forest belt. It differs from that form by the arrangement of the primary papillæ as set forth in the preceding key and from the varıety basilensis which it resembles more closely by the greater number of legs in the female. 

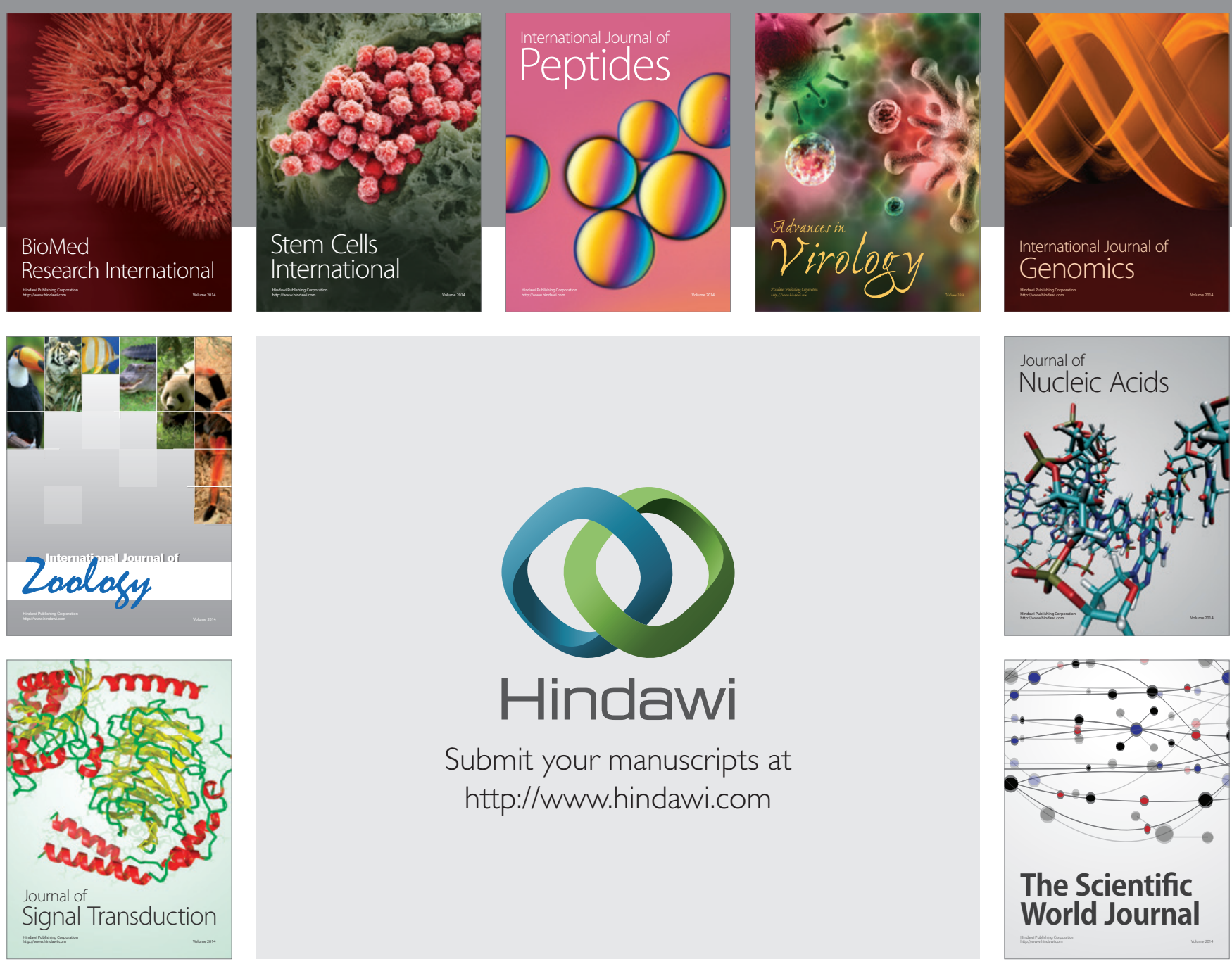

Submit your manuscripts at

http://www.hindawi.com
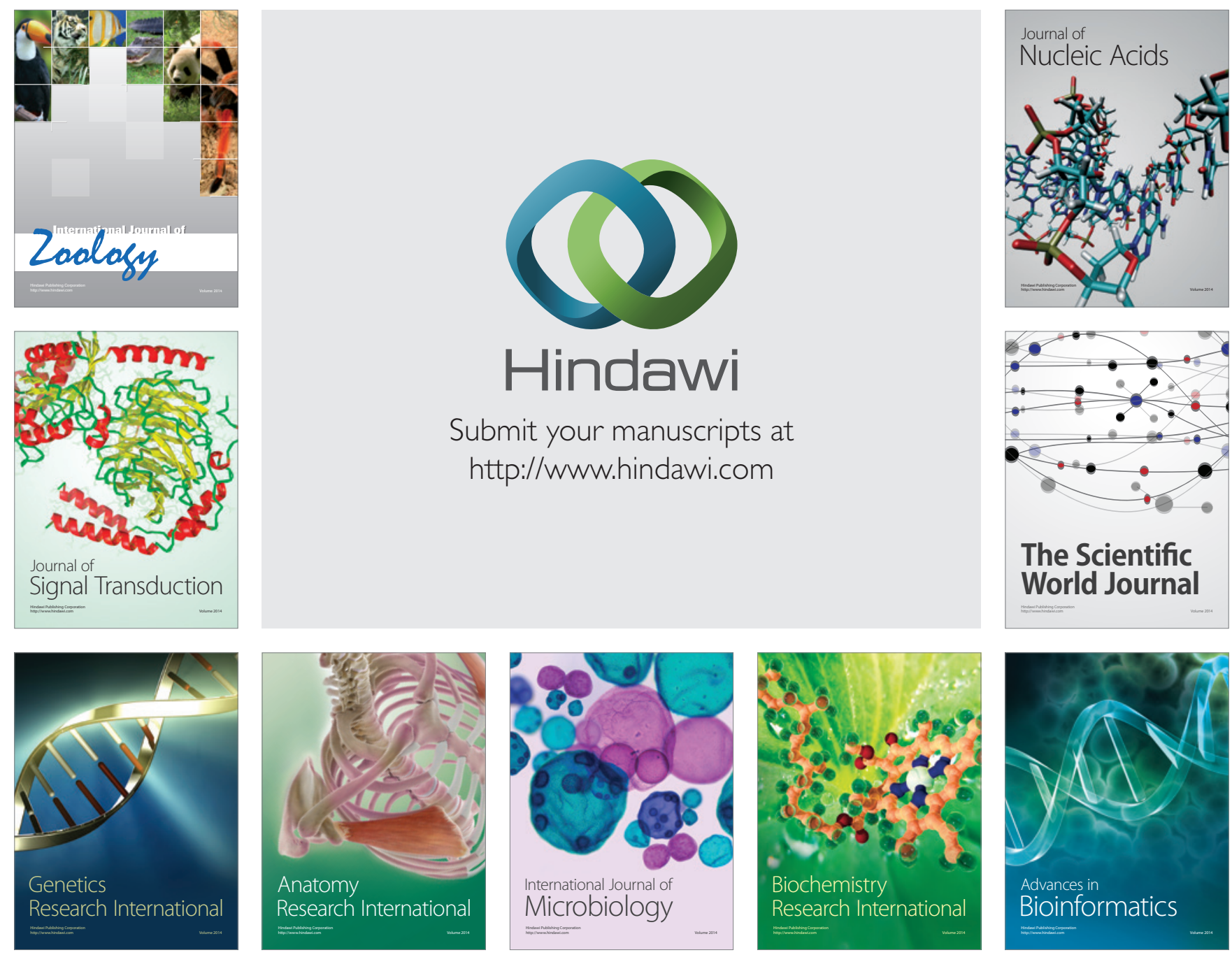

The Scientific World Journal
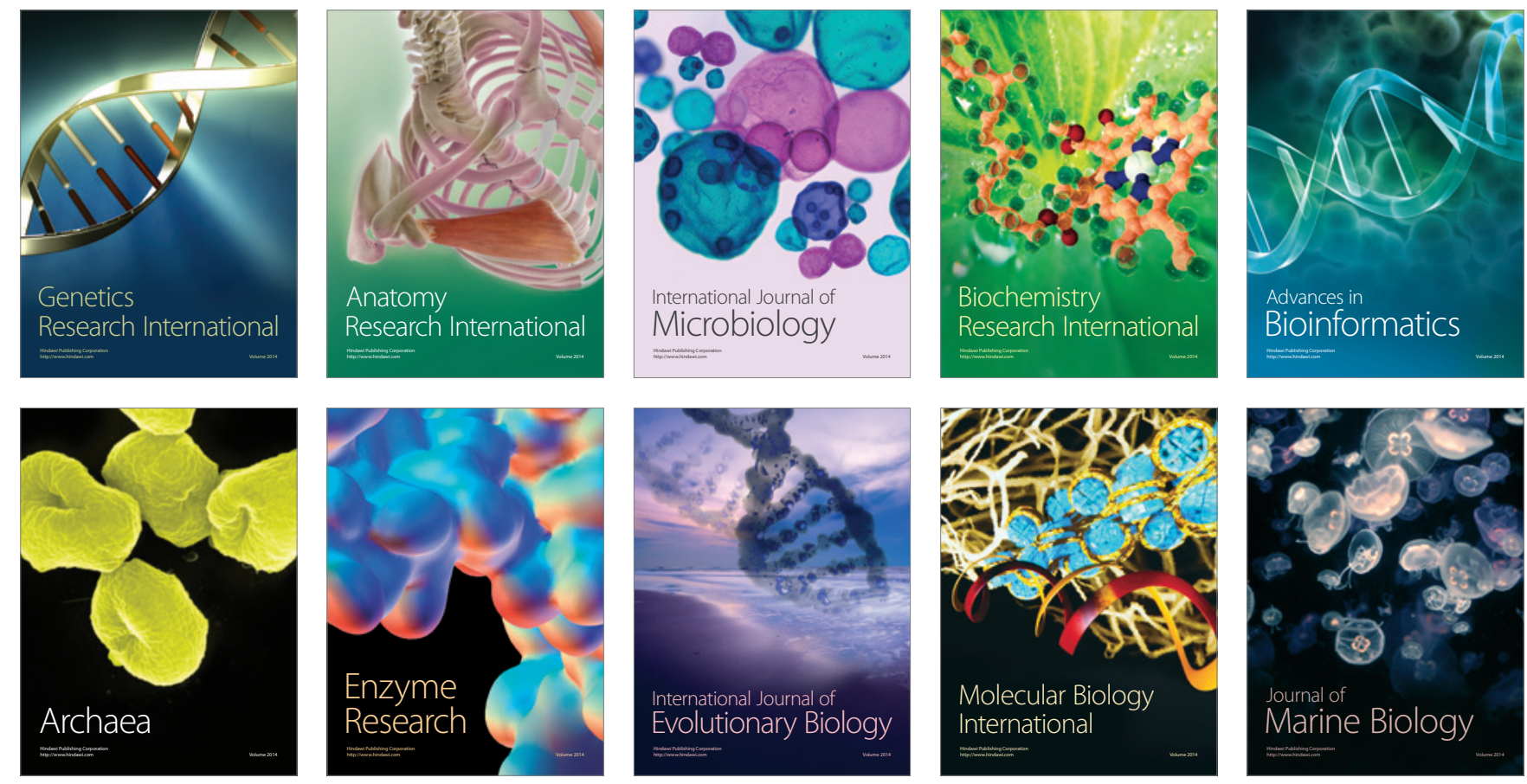